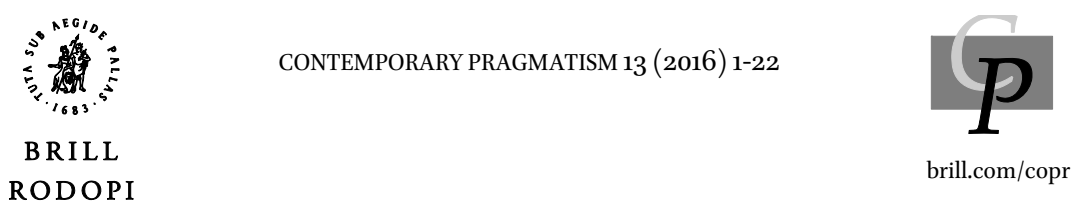

\title{
Liberation Pragmatism: Dussel and Dewey in Dialogue
}

\author{
Alex Sager \\ Portland State University, Portland, OR, USA \\ asager@pdx.edu \\ Albert R. Spencer \\ Portland State University, Portland, OR, USA \\ aspencer@pdx.edu
}

\begin{abstract}
Enrique Dussel and John Dewey share commitments to philosophical theory and practice aimed at addressing human problems, democratic modes of inquiry, and progressive social reform, but also maintain productive differences in their fundamental starting point for political philosophy and their use of the social sciences. Dussel provides a corrective to Dewey's Eurocentrism and to his tendency to underplay the challenges of incorporating marginalized populations by insisting that social and political philosophy begin from the perspective of the marginalized and excluded. Simultaneously, Dewey encourages a modest experimental and fallibilist approach to social transformation that promises more feasible social reforms than Dussel's approach rooted in phenomenology and the critical social sciences.
\end{abstract}

\section{Keywords}

Enrique Dussel - John Dewey - liberation philosophy - pragmatism - Latin American philosophy - democratic theory

(C) KONINKLIJKE BRILL NV, LEIDEN, 2016 | DOI 10.1163/18758185-01304005 
Our goal in this paper is to contribute to the construction of an American philosophy - not a philosophy of the United States, but an American philosophy that spans the continent from Argentina to Nunavut. Our strategy is to use the liberation philosophy articulated most prominently by Enrique Dussel and bring it into closer contact with the work of John Dewey. Enrique Dussel has suggested that "a return of the great philosophical theses of pragmatism is salutary, but this return will not be possible if the pragmatism of the North does not open up to a necessary dialogue with the impoverished, exploited, and excluded South." (Dussel 2013, 160) Dewey provides a promising focal point for this dialogue. Dewey and Dussel share commitments to philosophical theory and practice aimed at addressing human problems, democratic modes of inquiry, and progressive social reform, but also have productive differences in their fundamental starting point for political philosophy and their use of the social sciences.

Though the parallels between the Philosophy of Liberation and American Pragmatism have not gone unremarked (Pappas 2011; Stehn 2011a; Stehn 2011b), they merit further development. Pragmatist philosophers - including Dewey and his heirs - have neglected the Global South and have been too sanguine about including marginalized groups in developed states, illegitimately narrowing the scope of who is included in democratic dialogue and the set of problems addressed. Dussel provides a corrective to Dewey's Eurocentrism and his tendency to underplay the challenges of incorporating marginalized populations by insisting that social and political philosophy begin from the perspective of the marginalized and excluded. Simultaneously, Dewey's conception of democracy provides resources - most prominently a practical conception of democracy intimately connected to a pedagogical theory - for contextualizing and constructing North-South dialogues and social movements. Deweyian democracy encourages a modest experimental and fallibilist approach to social transformation that meets Dussel's insistence on political feasibility better than Dussel's approach rooted in phenomenology and the critical social sciences.

\section{Dussel and Dewey in Dialogue}

Enrique Dussel's philosophy emerges through explicit dialogue with other figures. His engagement in the 1970s with Emmanuel Levinas informed Philosophy of Liberation (1980/85) and his essays on Karl-Otto Apel, Richard 
Rorty, and Charles Taylor in The Underside of Modernity (1996) serve as fodder and as foils for his recent philosophy. Indeed, Ethics of Liberation in the Age of Globalization and Exclusion can be read as an exegesis and reconstruction of much of the philosophical tradition to construct a critical, non-Eurocentric philosophy. Given the breadth and depth of his engagement with the tradition, it surprising how little Dussel has explored John Dewey's ethical and political philosophy. ${ }^{1}$ Dewey receives no mention in Twenty Theses on Politics. Two volumes of Politica de la liberación contain only a single offhand remark of Dewey as a proponent of "democratic pragmatism" (Dussel 2009: 436). The Philosophy of Liberation (1980/1985) contains two disparaging remarks of Dewey as a follower of Rousseau and a propagandist of bourgeois culture. Though Dussel draws on American pragmatism as a resource in Ethics of the Liberation in the Age of Globalization and Exclusion, he focuses on the contributions of C.S. Peirce and Hilary Putnam. The attention to these two figures without serious attention to Dewey is surprising. Peirce wrote little on ethics and on political philosophy and Putnam is much better known for his contributions in other areas.

This absence is more remarkable given that liberation philosophy and Dewey's pragmatism share striking similarities. First, Dussel and Dewey share a commitment to naturalism, grounding their moral and political philosophy in a conception of human beings as animals in the natural world. ${ }^{2}$ For Dussel the universal principle of all ethics is "the obligation to produce, reproduce, and develop the concrete human life of each ethical subject in a community." (Dussel 2013, 55) At the basis of their ethics is human need. Dussel acknowledges the continuity between Liberation Philosophy and Pragmatism on this point with a quote from Hilary Putnam:

\footnotetext{
${ }^{1}$ Our interpretation of Dussel rests primarily on his work after the publication of Philosophy of Liberation in 1977. In our view, Dussel's position has shifted significantly through his analysis of Marx and his engagement with discourse ethics. We focus here on Ethics of Liberation in the Age of Globalization and Exclusion, the two published volumes of his Politica de la liberación, Twenty Theses on Politics, and his essays that anticipate and develop themes from the Ethics of Liberation.

${ }^{2}$ Contra Ofelia Schutte (1991), we consider Dussel's ethics and politics of liberation to be autonomous from his contributions to theology of liberation. Though philosophy of the liberation is influenced by radical Catholic social thought, its justification and content do not rely on revelation. For a useful discussion of the relationship between liberation theory and liberation philosophy, see Márquez 2010.
}

CONTEMPORARY PRAGMATISM 13 (2016) $\quad$ 1-22 
Ruth Anna Putnam, following the line of John Dewey [or Marx \{Dussel's insertion\}], appeals at this point to the notion of a need. It is because there are real human needs and not merely desires, that it makes sense to distinguish between better and worse values, and, for that matter, between better and worse...

quoted in DUSSEL 2013, 171

In Human Nature \& Conduct (MW 14), ${ }^{3}$ Dewey presents a genealogy of ethics which bears striking similarities to Dussel's notions of human need. Dewey sees systems of ethics as serving to control human nature and argues most ethoi impose structures contrary to human nature as a means of securing oligarchic control (6). By rooting our moral inquiries at the level of humans transacting with their biological and cultural environment, we can develop methods of inquiry that allow us to diagnose problems accurately, and provide a "fund of growing knowledge" (12).

Second, Pragmatism and the Philosophy of Liberation both take experience as the point of departure for ethics and political philosophy (Stehn 2011a, 25). Indeed, Pappas summarizes the initial and enduring affinity for Dewey in the Hispanic world as based on his "concern with practical lived experience; the conception of the individual as an organic whole and active in social relationships; and the importance of education as a process for living in the present and transforming society in a democratic direction" (8). Dewey explains this connection between experience and democracy as follows:

A democracy is more than a form of government; it is primarily a mode of associated living, of conjoint communicated experience. The extension in space of the number of individuals who participate in an interest so that each has to refer his own action to that of others, and to consider the action of others to give point and direction to his own, is equivalent to the breaking down of those barriers of class, race, and national territory which kept men from perceiving the full import of their activity... They secure a liberation of powers which remain

\footnotetext{
${ }^{3}$ Citations of Dewey are to the published works are by volume and page number of the critical edition, The Collected Works of John Dewey, 1882-1953, ed. Jo Ann Boydston (The Middle Works: 1898-1924 [MW], and The Later Works, 1925-1953 [LW]).
} 
suppressed as long as the incitations to action are partial, as they must be in a group which in its exclusiveness shuts out many interests.

MW 9, 94

Thus, for Dewey democracy is not merely a system of government, but a way of life that is continuous with education and lived experience. Furthermore, experience is social and created through communication and democracy flourishes when it is inclusively informed by the diverse ways of life it represents.

A third related point is that Dussel and Dewey share a commitment to democracy as the fundamental method and mechanism for social progress. Both see democracy as the most legitimate, effective, and empirical means for social organization and conflict-resolution. Dussel states that "Democracy is a perpetually unfinished system," a way of life that requires continual reconstruction and experimentation (Dussel 2008, 51). For Dussel, legitimacy has its basis in the people whose will is mediated by institutions. On his account, democracy...

...is an institutionalization of those mediations that allow legitimate decisions, actions, institutions, and delegated exercise of power. These are implemented through systems of empirical institutions that are invented, tested, and corrected by humanity throughout the millennia in order to achieve a strong measure of approval by the citizenry.

DUSSEL 2008, 62

This echoes Dewey's conception of democracy as the best social arrangement for directing human nature towards cooperative problem solving, the pursuit of common interests, and scientific inquiry. Dewey's political philosophy aims at the reconstruction of democracy so that it pervades all aspects of society - in the context of the United States, moving from Lyndon Johnson's Great Society to a Great Community, "a society in which the ever-expanding and intricately ramifying consequences of associated activities shall be known in the full sense of that word, so that an organized, articulate Public comes into being." (LW 2, 351) Scholars such as William R. Caspary aptly present Dewey as a "participatory democracy theorist" and stress the significance of democracy for social relationships and associations founding all aspects of human life (Caspary 2000, 8-9).

CONTEMPORARY PRAGMATISM 13 (2016) $\quad$ 1-22 
Fourth, Dussel draws inspiration from Paulo Freire's pedagogy in Ethics of Liberation in the Age of Globalization and Exclusion. Though there are important differences between Freire and Dewey's philosophy of education, there is also considerable common ground in Dewey's insistence on education allowing for the democratic identification of problems and the eventual transformation of society (Betz 1992). Dewey and Freire reject top down, elitist reforms in favor of reform driven by the people who have come to recognize their own interests through education and choose to participate in their own liberation.

Finally, Dussel and Dewey share a similar space on the left of the political spectrum, advocating radical reform. Dussel aims to reconstruct ethics from the perspective of the world's marginalized populations and draws on Marx to diagnosis and contest neoliberal social and economic policies and institutions, but his goal is transformation through gradual, but radical reform. He repeatedly admonishes anarchists who wish to destroy the state, insists on the need to build institutions that combine participatory with representative democracy, and stresses the imperfection of all actual institutions. He writes:

It is not sufficient to rest with spontaneous movements, with social, popular or antisystemic movements; political participation must be explicitly defined in the empirical sphere. That the people can demand the fulfillment of its needs through proposals put forward by the participative community, participate in the determining the budget, oversee and inspect the actions of all levels of representation, and, ultimately, revoke representatives' mandates, this signifies real participation that has left behind ineffective spontaneism.

DUSSEL 2011, 20

Dewey shares similar commitments, placing faith in the experimental intelligence of ordinary people and the capacity of universal education to equip them with the tools to engage intelligently in politics. The ultimate goal of society is "the production of free human beings associating with one another on terms of equality" (LW 13, 321). But Richard Bernstein notes, Dewey, who "was always skeptical of militant revolution, nevertheless advocated radical reform." (Bernstein 1991, 231)

Given these similarities, why has Dussel neglected Dewey? One unsatisfactory possibility is that Dussel has had limited direct contact with Dewey's work. Indeed, his references to Dewey's philosophy are often 
through secondary sources (Frank Cunningham for democracy, Richard Bernstein for Dewey's political attitudes) rather than an analysis of Dewey's major texts (Bernstein 1991, Cunningham 2002). Though it may be true that Dussel has not ready Dewey deeply or systematically, the question of why remains. Dussel's philosophical range is remarkably broad and we should assume that he has reasons for choosing not to immerse himself in the works of major figure. Our view is that Dussel's perception of Dewey is somewhat distorted and that he has not fully recognized the resources Deweyean pragmatism offers.

Dussel's most substantial discussion of Dewey in Ethics of Liberation in the Age of Globalization and Exclusion helps to reveal his attitude toward Dewey. Though this passage does not explicitly cite Dewey, it helpfully reconstructs how Dussel sees the differences between American pragmatism and philosophy of liberation:

In any event, the fundamental intuitions of pragmatism can be fully subsumed by an ethics of liberation, but with a difference: if pragmatism thinks preferentially from the experience of a scientific community, from the natural sciences (from Darwinism, for example), and from North American common sense, the ethics of liberation thinks primarily from the experience of the practical-political community, from the critical social sciences (its critique of global political economy, for example), and from the oppressed or excluded of the periphery, as well as those in the center.

DUSSEL 1998/2013, 166

This passage reveals a difference in perspective and in preferred tools. One of the major differences between Dussel and Dewey is that Dussel's later philosophy is deeply informed by his engagement with Marx while Dewey's knowledge of Marx was limited and filtered by Soviet doctrine (Cork 1950). Dewey wrote little about global political economy, whereas Dussel is influenced by dependency theory and Immanuel Wallerstein's World Systems Theory. Though Dewey's philosophy is certainly influenced by Darwinism (MW 4, 1909) and is arguably informed by North American common sense (though it is somewhat unclear what this amounts to), this distinction is too stark. Dewey's democratic thought departs from the experience of the practical-political community and is by no means scientistic. Moreover, there is nothing about American pragmatism that disallows deeper engagement with critical theory and with radical political

CONTEMPORARY PRAGMATISM 13 (2016) $\quad \mathbf{1 - 2 2}$ 
economy (Frega 2014). Nor is it obvious why liberation philosophy should not draw on Darwinianism and other well-established scientific theories where relevant.

A couple sentences later Dussel remarks that "pragmatism could not discover the phenomenon of Eurocentrism, because it interpreted the United States as the full Western fulfillment of Europe." (Dussel 2013, 166) A footnote to this passage comments on a passage from Reconstruction in Philosophy (MW 12, 101-2) in which the discovery of the Americas is recounted from the perspective of European explorers. It reads:

...when Dewey speaks of Modernity with its 'romantic sense of adventure into novelty,' in which he includes everything from the Crusades to 'the finding and opening up of North and South America', and this latter aspect is perceived as an 'obvious external fact,' which then belongs to the same 'tradition of novelties. There is no rupture of consciousness of being something different than Europe. ... America is an object ripe for a romantic 'finding and opening,' and not the subject of a traumatic conquest or 'invasion' that devastated the continent's Amerindian cultures, that included violence commerce in African flesh, and so on. Pragmatism is up to now the new and great philosophy of the 'West,' situated in the 'hegemonic' region of the 'center' of the world system at the beginning of the twenty-first century.

DUSSEL 2013, 541064

On this interpretation, Dewey's thought derives from the perspective of the dominant power and is blind to its effects on the victims of imperialism and colonialism. ${ }^{4}$ Dewey claims universality while unwittingly assuming the perspective of those in power, whereas liberation philosophy consciously begins from the perspective of the excluded and oppressed. As a result, Dewey's pragmatism attempts to reform the existing system without offering redress to its victims, whereas liberation philosophy aims to transform the system by bringing the victims into the democratic process as equals.

Is this criticism is fair to Dewey? Dussel does not believe that moral and political ideas can be divorced from their geopolitical and historical context (Dussel 2013, 47). He identifies pragmatism as "the philosophy of the United

${ }^{4}$ For a discussion of this possibility, see Margutti 2013. 
States" (Dussel 2013, 160) and the United States is the center of the world system. At the turn of the century, William James could deliver his Gifford lectures as a New World interloper. Dewey lived until the middle of the twentieth century and established himself as the American philosophy during a time when the United States had become the leading world power. Arguably, his conviction that Dewey approaches the Americans from the perspective of the European colonizer, has led Dussel to no see a need to immerse himself in Dewey's work.

This speculation on the possibility of Dussel's geopolitical stance contributing to his relative neglect is supported by Gregory Pappas who has noted that pragmatism has suffered an uneven reception in Latin America. During the early twentieth century pragmatism represented an attractive alternative for philosophers of the Americas because it was "empirical and informed by the sciences" but "neither scientistic nor reductionistic" thus it functioned as an alternative to positivism which was sometimes "used in Latin America to justify dictatorships and threaten values and beliefs dear to Latin Americans" (Pappas 2011, 4). But by the late twentieth century, "negative but mistaken views of pragmatism as a variety of positivism or as a shallow American-style utilitarianism" coupled by an "invasion" of "existentialism and analytic philosophy" resulted in the eclipse of pragmatism until Richard Rorty's publication of Philosophy and the Mirror of Nature (1979) (Pappas 2011, 5).

Dussel appears to share this negative understanding of pragmatism, an understanding reinforced by his dialogue with Richard Rorty who often represented himself as a Deweyean. Dussel applauds Rorty's attention to cruelty (Rorty 1989) as a "profoundly ethical attitude" (Dussel 1996, 104) and quotes Rorty's invocation of solidarity as "created by increasing our sensitivity to the particular details of the pain and humiliation of other, unfamiliar sorts of people." (Dussel 1996, 112, c.f. Rorty xvi) Nonetheless, he rejects Rorty's dismissal of Marx and sees his non-foundationalist, hermeneutical ethnocentricism as lacking the tools to move beyond conversation to socio-historical and economic-political analyses of injustice. For example, Dussel writes the following of his discussion with Rorty on Dewey and Marx and the possibility of pragmatism incorporated the critical social sciences:

I asked Rorty at the philosophy institute in Mexico: 'Pragmatically, in Dewey's sense, speaking, if someone is in misery, in absolute poverty, with a salary of 50 dollars a month, with five children, living in a house made of cardboard, etc., which language will be 'pragmatically,' more useful: either the banalization or the serious consideration of Marx's language which tries

CONTEMPORARY PRAGMATISM 13 (2016) $\quad \mathbf{1 - 2 2}$ 
to rationally explain the causes of their pain, and who pronounced the law of accumulation' thus: the accumulation of wealth is the reverse of the accumulation of misery? Rorty could not but answer that Marx's language would be more useful. With this the entire question of Liberation Philosophy becomes clear, at least from the point of view of Dewey's 'pragmatism'!" (Dussel 1996, 127n110).

Nonetheless, in a footnote to Ethics of Liberation in the Age of Globalization and Exclusion, Dussel suggests "an ethics of liberation could be closer to that of a 'Deweyian pragmatist' than to that of the 'aestheticism' of Rorty." (Dussel 2013, 540n62) This may suggest more of an affinity between the two philosophies - or at least openness on the part of Dussel that Deweyean pragmatism may not need to be subsumed.

\section{Toward Liberation Pragmatism}

The parallels between Dewey and Dussel invite dialogue, but the reason for bringing them together is that this may address shortcomings in both pragmatism and liberation philosophy. Alexander Stehn has remarked that the major difference is that classical pragmatism claims to be a philosophy of "general experience, when it is actually setting out from a historical experience that is located in the privileged center of a global system whose development began with the violent colonization (not discovery) of the Americas" whereas "Liberation Philosophy begins with the experience of the oppressed" (Stehn 2011a, 19). Stehn attempts to show how the two philosophies may lead "to the same liberating project of social and political reconstruction" and defends pragmatism as "in aspiration, a liberatory philosophy of much broader scope and deeper significance" (Stehn 2011a, 25).

Though we are broadly sympathetic to Stehn's analysis, he understates crucial differences between American Pragmatism and Liberation Philosophy. These differences open up the possibility of developing conceptual and normative tools for the transformation of social and political institutions to be more equitable and to better fulfill human needs. Dussel provides a critical philosophy that is alive to how dominant institutions exclude, marginalize, and harm the most vulnerable, but his phenomenological roots and suspicion of social science strips him of the tools for feasible, radical reform. Dewey's empiricism and experimentalism offers tools for implementing and assessing institutional change that aligns well with the more successful progressive movements in Latin America. Closer contact between American Pragmatism and Liberation Philosophy 
offers a more robust, democratic, pragmatic philosophy of liberation that connects to contemporary social and political movements in Latin America and the rest of the world.

Dussel articulates a critical political philosophy that helps explain how new social movements of excluded groups can transform institutions that exclude and dominate them. Following the structure of his ethics, Dussel divides political philosophy into three spheres, each with its own principle: a material principle, a formal principle, and a principle of feasibility (Dussel 2008, 57-9). ${ }^{5}$ The material principle is concerned with human needs ranging from nourishment and shelter to the need to reproduce culture and to participate as a member of the community. It provides the content for politics which exists for the promotion of life: "Politics deals with creating the conditions of possibility for and advancement of the life of the community and each of its members: a possible life, a qualitatively better life." (Dussel 2008, 6o) The formal principle in politics draws on Apel and Habermas's discourse ethics to develop democratic procedures to ensure legitimacy. Dussel adds the requirement that the material and formal elements of a political theory must support feasible proposals. Institutions serve as "administrative instruments that allow the fulfillment of the specified goals of the other two spheres (the material and formal spheres)." (Dussel 2008, 63) This feasibility principle unites theory and practice.

The each of these spheres has a "critical" aspect. All political systems exclude and harm part of the population. At the material level, some people are hungry, at the formal level, they are voiceless, and at the level of feasibility, political institutions do not fulfill their role. A central task for radical political philosophy is to participate in the quest for feasible institutions that fulfill the material needs of excluded people and give them a democratic role. Dussel seeks a

\footnotetext{
${ }^{5}$ We do not engage here Dussel's rereading of the history of philosophy in the first part of Ethics of Liberation and the first volume of Politica de la Liberación that attempts to dispel the Eurcentricism of the philosophical tradition. This work is crucial for reorienting philosophy to account of the experience and perspective of the periphery.
} 
"subjectivized state" in which the citizens will participate to such a degree that the existing institutional sphere will shift toward transparency, the bureaucracy will be the minimum necessary, while its efficacy and instrumentality when it comes to the permanence and extension of human life will nevertheless be at a maximum.

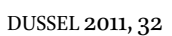

How is the transformation of political institutions to be achieved? Dussel sees the basis of all political institutions (potestas) as ultimately resting on the power of the people (potentia) (Dussel 2008, 26). Transformation requires that representative democracy be integrated with participatory democracy (Dussel 2008, 128). The aim is to achieve agreement that allows the affected to "participate in the fullest way possible ... through reasonable discussion (without violence) with the highest possible degree of symmetry among participants, taking place publicly and according to the democratic institutional structure agreed upon beforehand." (Dussel 2008, 64-5) Democracy is an unfinished process, always with unanticipated effects and "victims" who are harmed by policies and excluded from decision-making.

Political institutions pass through stages of development. Initially, they appear to respond to unmet demands and needs. When the institutions enjoy consensus "which unites wills and binds power as a joint force" (Dussel 2008,39 ), they are defensible. As they mature, they begin to fail to fully fulfill some of the functions that justify their existence. Crisis arises when institutions become "bureaucratic, self-referential, oppressive, and nonfunctional" and are treated as ends in themselves (rather than as mechanisms for fulfilling needs) (Dussel 2008, 45). At this stage, consensus fades, institutions become coercive, and power becomes fetishized, "selfgrounded on its own despotic will" (Dussel 2008, 34). This leads to popular movements that seek to transform them.

A critical political philosophy should guide us in the process of political transformation, changing the system to incorporate more people and to remove these bad effects. Political philosophy, on Dussel's (and on Dewey's) account, should not strive merely to provide regulative ideals to evaluate current institutions and reforms. Rather, it should unite theory and practice with a keen eye toward feasibility.

Liberation Philosophy offers pragmatism a perspective that privileges the excluded, marginalized populations and a vocabulary that encourages a vivid, affective connection to the oppressed. Dewey's reflections on the public often fail to recognize the extent to which significant parts of the 
population are simultaneously excluded from democratic participation and disproportionately harmed by dominant institutions. Dewey's political philosophy acknowledges how powerful groups and institutions exercise illegitimate power over others, but rarely discusses this in concrete detail. American Pragmatism also tends to have a parochial focus. Though Dussel overstates the extent to which pragmatism is complicit in colonial and imperial projects, Dewey was very much an American (i.e., from the United States) intellectual, despite his writings and travels to Russia, Japan, and Mexico. Liberation Philosophy demands a global perspective, something which pragmatism has not achieved.

We see this neglect in Dewey's discussion of education as an inclusive mechanism. Dewey contends that increased contact between diverse groups will promote the democratic ideal in terms of "more numerous and more varied points of common interest." (MW 14, 92) He writes:

The extension in space of the number of individuals who participate in an interest so that each has to refer his action to that of others, and to consider the action of others to give point and direction to his own, is equivalent to the breaking down of those barriers of class, race, and national territory which kept men from perceiving the full import of their activities.

MW 14, 93

Dewey is too sanguine in assuming a bedrock of common interest and in seeing the inclusion of more people as a straightforward means of breaking down social barriers. He neglects how mechanisms of exclusion and domination act precisely to reinforce these barriers, at times using the guise of neutrality and inclusive rhetoric to avoid structural changes. Dussel's criticisms of Karl-Otto Apel and Jürgen Habermas's discourse ethics are pertinent here. Procedural mechanisms for justifying norms are only effective if everyone has the opportunity to participate and to have their voices heard. In practice, many people are excluded from the dominant community of communication altogether or find their reasons and experience dismissed by the dominant community (Young 2010). Dewey shares Apel and Habermas's blindness to the "the multiple ordinary asymmetrical processes of domination of women, discrimination against certain races, suffocation of peoples and indigenous cultures, and oppressive pedagogical processes." (Dussel 2013, 295)

CONTEMPORARY PRAGMATISM 13 (2016) 1-22 
In contrast, Dussel draws on Paulo Freire's concept of concientizaçao in which learners acquire a critical understand of reality through the process of popular education (Dussel 2013, 314, c.f. Freire 1970). Though Dewey and Freire share many educational ideals and goals (Betz 1992), Freire stresses education's role in awakening and empowering marginalized populations. The educational process, conceived by Freire, is a dialogue in which people achieve their liberation through a progressive understanding of a reality that needs to be transformed. Critical pedagogy leads to "the production of an ethical-critical consciousness" that "originates in the victims themselves by virtue of their being the privileged historical subjects of their own liberation." (Dussel 2013, 320) On Dussel's account, "Critical dissent becomes public only when it is supported by an organized community of dissenters (the victims) who struggle for recognition and who fight against the system's truth and validity in light of the impossibility of living and of their exclusion from the discussions that affect them." (Dussel 2013, 347)

Dussel's critical philosophy and global focus serve as a welcome corrective to Dewey's ethics and political philosophy. Where he falls short is in providing the tools to realize his ethical vision. His political philosophy often takes on an amorphous, metaphysical quality inherited from his phenomenological roots. For instance, he tells us that the "ultimate foundation of all power" (Dussel 2008, 18) is the community, but that "Originary power (potentia) as such is indeterminate (still not-anything), and is accordingly with any 'lack' but also without real or empirical existence." (Dussel 2008, 19) Potentia is the basis of all power, but it is exercised empirical through acts and institutions that may or may not conform to the will of the people. At this level of abstraction, it is difficult to know how potentia is constituted and what an empirical manifestation of potentia might be. Additionally, Dussel's conception of the people is unclear. He writes:

In the process of creating a hegemonic bloc, the need arises for a category that can encompass the unity of all the movements, classes, sectors, etc., in political struggle. And so the people [pueblo] is that strictly political category (since it is not properly sociological or economic) that appears as absolutely essential, despite its ambiguity (and indeed this ambiguity does not result from misunderstanding but rather from inevitable complexity).

DUSSEL 2008, 73

CONTEMPORARY PRAGMATISM 13 (2016) 1-22 
According to this passage, the people is unified enough to form a hegemonic bloc and encompasses all movements, but at the same time is ambiguous due to its inevitable complexity. How do we reconcile the contradictions here? Dussel continues this passage with a selection from a speech by Fidel Castro that refers to the people as the "vast unreedemed masses" (la gran masa irredenta) (Dussel 2008, 73) A number of problems arise.

First, Dussel's use of the term people is vague and totalizing, reducing individuals to a metaphysical category. Despite his protests, it does not allow for irreducible pluralism among groups. Who are Castro's "unreedemed masses"? In the passage cited, Castro mentions farm laborers, industrial workers, small business men, teachers and professors, and young professionals. Dussel mentions that Castro adds abandoned children, women, and the elderly in later speeches. It is hard to see how these people and their interests and goals fit together.

Second, Dussel's abstractions pose problems for a critical political philosophy. Dussel's term "victims" implies passivity "as hungry, poor, marginalized, in short, in need of liberation." (Schutte 1991, 283). Schutte continues: "the people remain the object that is thought about rather than a group of persons endowed with the capacity to think for themselves, to overcome obstacles by their own initiative, to triumph over their oppressors, and to rule their own destiny." (Schutte 1991, 283) This results in "a tendency to oversimplify the nature of liberation and of oppression, at a critical historical moment when just the opposite of this is what the discipline of philosophy ought to accomplish." (Schutte 1991, 281) Schutte calls for a "more realistic standpoint" that takes into account the population's diversity and provides mechanisms for conflict resolution (Schutte 1993, 205).

Third, Dussel is not particularly interested in actual democratic mechanisms, remaining caught at a level of abstraction. He refers to Chapter 4 of title 2 in the 1999 Constitution of the Bolivarian Republic of Venezuela as a model for this sort of reform (Dussel 2008, 127) and its mix of mechanisms "for the participation and the protagonism of the people in exercising its sovereignty in the political realm: elections to public posts, referenda, popular consultations, revoking mandates, and legislative, constitutional, and constituent initiative, open councils, and citizen assemblies whose decisions will be binding." (Dussel 2008, 127) Still, his work does not contain any sustained analysis of the effects of Chavez's Bolivarian Revolution which, judging by ongoing mass protests against violence, inflation, price controls, and corruption and their violent suppression by the Maduro government, has hardly been exemplary (Human Rights Watch 2014). Dussel makes frequent political statements about social and political policies and

CONTEMPORARY PRAGMATISM 13 (2016) $\mathbf{1 - 2 2}$ 
institutions, but demonstrates little patience for the difficult empirical task of assessing actual practice and policy.

This seems in part due to a conception of political philosophy as autonomous from social science. Dussel writes:

Political philosophy proposes neither concrete empirical projects nor transformations. This task falls to groups of social scientists, political parties, and social movements, on the economic and ecological levels, in education and health care, etc. Here we can only hope to explain principles, the fundamental criteria for transformation in the medium term (fifty years, for example), that will see the overcoming of the old authoritarian or totalitarian Latin American model as well as the recent neoliberal model applied during the last decades of the twentieth century.

DUSSEL 2008, 108

Dussel's neglect of the non-critical social sciences deprives him of resources for building institutions. Twenty Theses on Politics ends with a ragbag of underdeveloped proposals from the creation of a political block between South America, Central, America and the Carribean (138), instantiating a universal basic income, adopting Sen's capabilities approach (133) and the dissolution of the State in favor a virtual state (118). His remarks on the possibility of the need to "democratize communication media" amount to little more than platitudes and his suggestion about how an "electronic revolution" can allow for citizen participation (Dussel 2008, 132) shows no consideration of the many obstacles to high quality, effective participation. "community of networks" (Morozov 2011).

These limitations are problematic according to the standards Dussel sets for himself. On Dussel's account, the ultimate test for an ethical theory is its practical application. Unfortunately, his phenomenological and hermeneutical roots and his accompanying neglect of mainstream social science are a liability for a feasible political philosophy. Dussel's historical reevaluation of the tradition has a vital critical function, but it is of limited use in the construction of viable institutions to uphold political transformations.

This goal can be better reached an alliance with Deweyian pragmatism. Dewey himself is guilty of often offering general or vague prescriptions (MacGilvray 1999, 559) and, as we noted above, imposing an illegitimate degree of homogeneity on the population (Talisse 2011). Nonetheless, his 
experimental method has led his heirs to pursue more concrete and empirical work in politics and education. ${ }^{6}$ In the final section, we explore some of this work in the context of Latin American political movements.

\section{Applications: Pragmatic Democratic Practice in Latin America}

The Philosophy of Liberation would benefit from engagement with the actual social movements occurring in Latin America today. Building institutions is complicated and their normative evaluation requires empirical study. Latin America social movements have achieved widespread success in constructing democratic institutions in the face of neoliberal economic policies and a historical culture of clientelism. These movements are not without tensions and setbacks, in part because el pueblo is not a unified, undifferentiated mass, but rather consists of diverse groups with different concerns:

Contemporary Latin America is marked by movements that display a diversity of positions and strategies vis-à-vis the state, producing promising experiments of transformative politics through dynamic state-movement relations, but also disappointments as governments have responded to social protests with co-optation, repression and the delegitimizing of social movements.

STOKKE and TÖRNQUIST 2013, 13

We follow Gregory Pappas as seeing pragmatism as a "Resource in the Hispanic Experience for the Twenty-first Century" because it values "experience and practice override speculation and dogma," the "hope of an amelioration of concrete problems instead of a faith in inevitable progress," the "importance of the adequacy of means," a "break with tradition that favored reconstruction over revolution," "education as inseparable from

${ }^{6}$ See John Dewey's Educational Philosophy in International Perspective: A New Democracy for the Twenty-First Century. Larry Hickman \& Giuseppe Spadafora, eds. (Carbondale, ID: Southern Illinois University Press, 2009) and Continuing Relevance of John Dewey: Reflections on Aesthetics, Morality, Science, and Society. Larry Hickman, Matthew C. Flamm, \& Krzysztof P. Skowronski, eds. (Editions Rodopi, 2011).

CONTEMPORARY PRAGMATISM 13 (2016) $\quad$ 1-22 
political reform," experimentation, and a rejection of "atomistic individualism, certainty, decontextualized rationality, and other Enlightenment fictions" (11). Pragmatism's ideals can be mobilized on behalf of a democratic vision as a bottom-up, grass-roots process, and a democratic reconstruction that is sensitive to context," and "trusts people to figure out the means to their own liberation" (11).

Archon Fung has drawn on classical pragmatism, particularly John Dewey's work, as an important precedent for a problem-driven theory of democracy that is closely linked to empirical theory. On his account, pragmatism provides a valuable theoretical framework because of its commitment to the use of reflective intelligence to respond to practical problems, its evaluation of institutional design based on their consequences, its fallibilism, its commitment to institutional variation and choice, and its rejection of a fact-value dichotomy (Fung 2007, 445-6).

Fung along with Erik Olin Wright and their collaborators have referred to the ways in which "ordinary people can effectively participate in and influence policies which directly affects their lives" as Empowered Participatory Governance (EPG) (Fung and Wright 2003, 5). Their project closely parallels Dussel's prescriptions, but with a commitment to rigorous, social science: "EPG presses the values of participation, deliberation, and empowerment to the apparent limits of prudence and feasibility." (Fung and Wright 2003, 5)

Latin America is a fecund source of political movements and innovations that deserve and need assessment. As Dussel has noted,

Latin American has seen as sort of "political spring" which has been developing since the birth of many new social movements - the Mothers of the Plaza de Mayo, the Argentinean piqueteros, the movements by the landless and by the coca farmers, the indigenous movements in Ecuador, Bolivia, Guatemala, and elsewhere - that have come together at the World Social Forum in Porto Alegre"

DUSSEL 2008, XV

\footnotetext{
${ }^{7}$ In an intriguing parallel, Brazilian social and legal theorist Roberto Unger proposes "democratic experimentalism" and insists that "Institutional debates and experiments are not a separate and subsidiary exercise; they represent our most important way of defining and redefining the content of our ideals and interests." (Unger 1998, 18). Like Dussel, Unger advocates "radical reform as a species of transformative politics." Also see West 1988.
} 
These popular movements have sometimes coincided with the rise of political leaders on the left such as Nestor Kirchner, Tabaré Vásquez, Luiz Inácio Lula da Silva, Hugo Chávez, and Evo Morales. As Dussel recognizes, one of the most challenging questions concerns how to combine popular movements with representative democracy.

Leonardo Avritzer and Gianpaolo Baiocchi's work on participatory budgeting in Brazil provides a template for the sort of measures - and accompanying research - that might lead to a more sustainable model in the spirit of Dewey experimentalism and of Deweyian and Dusselian radical reform (Avritzer 2002, 2009, Baiocchi 2003, 2004). In Brazil, an alliance between the urban social movements and the Workers' Party (Partido dos Trabalhadoes) led to the widespread rise of participatory institutions, most prominently participatory budgeting. Though the success of these institutions has varied (Avritzer 2002), these experiments provide an opportunity to analyze different conditions and designs.

This is a project closely connected to the ideals of Deweyean pragmatism and congruent with Dussel's ambitions. What is notable about public participation in Brazil and many other places in the developing world is that it involves significant sectors of people who have traditionally been excluded from political decision making. These social experiments are by no means above criticism, but they provide the materials to learn about the creation of institutions that allow members of the public a substantial role and voice by supporting projects that meet their interests and needs. Engagement with empirical work guided by the vision supplied by Dussel's liberation philosophy offers a promising synthesis for a global ethical and political philosophy. Likewise, Dewey's empiricism and experimentalism offers tools for implementing and assessing institutional change that aligns well with the more successful progressive movements in Latin America. Closer contact between American Pragmatism and Liberation Philosophy offers a more robust, democratic, pragmatic philosophy of liberation that connects to contemporary social and political movements in Latin America and the world.

\section{Acknowledgements}

The authors would like to thank the organizers and participants of both the 2014 meeting of The North American Society for Social Philosophy at Southern Oregon University in Ashland, OR and the 2015 Trans-American Experience Conference at The University of Oregon in Eugene, OR for

CONTEMPORARY PRAGMATISM 13 (2016) $\quad$ 1-22 
accepting and responding to early drafts of this work. They would also like to thank the members of the Portland Political Theory Symposium for reading and discussing a later draft. We honor your feedback and support.

\section{Bibliography}

Avritzer, Leonardo. 2002. Democracy and the public space in Latin America. Princeton: Princeton University Press.

Avritzer, Leonardo. 2009. Participatory Institutions in Democratic Brazil. Washington, D.C.: Woodrow Wilson Center Press.

Baiocchi, Gianpaolo, ed. 2003. Radicals in Power. London and New York: Zed Books Ltd.

Baiocchi, Gianpaolo. 2003. "Participation, Activism, and Politics: The Porto Alegre Experiment." In Deepening Democracy: Institutional Innovations in Empowered Participatory Governance, edited by Archon Fung and Eric Olin Wright, 45-76. New York, NY: Verso.

Betz, Joseph. 1992. "John Dewey and Paulo Freire." Transactions of the Charles $S$. Peirce Society 28 (1): 107-26.

Bernstein, Richard J. 1991. The New Constellation: The Ethical-Political Horizons of Modernity/Postmodernity. Cambridge, Mass: MIT Press.

Caspary, William R. 2000. Dewey on Democracy. Ithca, NY: Cornell University Press.

Cork, Jim. 1950. "John Dewey and Karl Marx." In John Dewey: Philosopher of Science and Freedom, edited by Sidney Hook. New York, NY: Barnes and Noble Inc.

Cunningham, Frank. 2002. Theories of Democracy. A Critical Introduction. Routledge: London.

Dewey, John. 2008. The Middle Works, 1899-1924. Edited by Jo Ann Boydston. Carbondale: Southern Illinois University Press.

Dewey, John. 2008. The Later Works, 1925-1953. Edited by Jo Ann Boydston. Carbondale: Southern Illinois University Press.

Dussel, Enrique. 1996. The Underside of Modernity. Atlantic Highland, NY: Humanities Press.

Dussel, Enrique. 2007. Política de la Liberación, Volumen I: Historia mundial y crítica. Madrid: Editorial Trotta.

Dussel, Enrique. 2008. Twenty Theses on Politics. Durham, NC: Duke University Press.

Dussel, Enrique. 2009. Política de la Liberación, Volumen II: La arquitectónica. Madrid: Editorial Trotta.

Dussel, Enrique. 2011. Carta a los indignados. México, D.F.: La Jornada.

Dussel, Enrique. 2013. Ethics of Liberation: in the Age of Globalization and Exclusion. Durham NC: Duke University Press. 
Frega, Roberto. 2014. "Between Pragmatism and Critical Theory: Social Philosophy Today." Human Studies 37: 57-82.

Freire, Paulo. 1970. Pedagogy of the Oppressed. Translated by Myra Bergman Ramos. New York, NY: Continuum.

Fung, Archon. 2007. "Democratic Theory and Political Science: A Pragmatic Method of Constructive Engagement.” American Political Science Review 101(3): 443-458.

Fung, Archon and Eric Olin Wright. 2003. Deepening Democracy: Institutional Innovations in Empowered Participatory Governance. New York, NY: Verso.

Human Rights Watch. 2014. "Punished for Protesting: Rights Violations in Venezuela's Streets, Detention Centers, and Justice System." http://www.hrw.org/sites/default/files/reports/venezuelao514_reportcover_web.p df.

Márquez, Iván. 2010. "Liberation in Theology, Philosophy, and Pedagogy." In $A$ Companion to Latin American Philosophy, edited by Susana Nuccetilli, Ofelia Schutte, and Otávio Bueno. Malden, MA: Wiley Blackwell.

MacGilvray, Eric A. 1999. "Experience as Experiment: Some Consequences of Pragmatism for Democratic Theory." American Journal of Political Science 43(2): $542-565$.

Margutti, Paulo. 2013. "Pragmatism and Decolonial Thinking: An Analysis of Dewey's Ethnocentrism." Cognitio 14(1): 63-83.

Morozov, Evgeny. 2011. The Net Delusion: The Dark Side of Internet Freedom. New York, NY: Public Affairs.

Pappas, Gregory Fernando, ed. 2011. Democracy in the Americas. NY, New York: Fordham University Press.

Rorty, Richard. 1989. Contingency, irony, and solidarity. Cambridge, uK: Cambridge University Press.

Schutte, Ofelia. 1991. "Origins and tendencies of the philosophy of liberation in Latin American thought." The Philosophical Forum. 22(3): 270-95.

Stehn, Alexander V. 2011a. "El Pueblo and Its Problems: Democracy of, by, and for Whom?" The Pluralist 6(3): 103-116.

Stehn, Alexander V. 2011b. "Toward an Inter-American Philosophy: Pragmatism and the Philosophy of Liberation." Inter-American Journal of Philosophy 2(2):14-36.

Talisse, Robert B. 2011. "Toward a New Pragmatist Politics." Metaphilosophy 42(5): $55^{2-71}$.

Unger, Roberto. 1998. Democracy Realized: The Progress Alternative. London and New York: Verso.

West, Cornel. "Between Dewey and Gramsci: Unger's Emancipatory Experimentalism." Northwestern University Law Review 81, no. 4 (1988): 941-52. Young, Iris Marion. 2010. Inclusion and Democracy. Oxford: Oxford University Press.

CONTEMPORARY PRAGMATISM 13 (2016) 1-22 


\section{Author Queries}

AQ1: Please check the unpaired quotation mark in the sentence "With this the entire...Dewey's 'pragmatism'!".

AQ2: Reference Stokke and Törnquist (2013) is cited in the text but not provided in the reference list. Please check.

AQ3: Please check the unpaired quotation mark in the sentence "Pragmatism's ideals...sensitive to context,"

AQ4: Please check the unpaired quotation mark in the sentence "Latin American has...Porto Alegre".

AQ5: Reference Baiocchi (2004) is cited in the text but not provided in the reference list. Please check.

AQ6: Reference Dussel (2007) is provided in the reference list but not cited in the text. Please check. 